\title{
Incentives in Corporate Governance: the Role of Self-Regulation*
}

\author{
Paolo Di Betta**, Carlo Amenta***
}

\begin{abstract}
Corporate governance stems from the interplay of legal norms, security regulation, self-regulation and best practices. Recent scandals and frauds have forced governments to update laws on corporate governance: the legislation process has been very fast in some countries, others have lagged.

Law and regulation intervene and become effective only ex-post, when damages have been done and malpractice is self-evident. On the contrary, self-regulation is a quicker and more flexible response to changing market conditions and of great impact on the relationship between firms and their environment.

A self-regulatory organization (SRO) such as the stock exchange could administer the screening device, based on an indicator developed on the provisions of the corporate governance code issued by the SRO itself.
\end{abstract}

Keywords: Corporate Governance; Regulation; Security Regulation; SelfRegulation; Corporate Governance Code; Global Finance; Global Investors

\section{A Perspective on Corporate Governance}

Corporate governance stems from the interplay of legal norms, security regulation, self-regulation (including corporate governance codes and instructions for listed firms) and best practices. Recent scandals and frauds have forced governments to update laws on corporate governance: the legislation process has been very fast in some countries, others have lagged, the final result being in any case an increase in the costs of mantaining a proper corporate governance system caused and a recess in the relevance given to existing self-regulation tools.

The gist of our argument is that law and regulation intervene and become effective only ex-post, when damages have been done and malpractice is selfevident. On the contrary, self-regulation is a quicker and more flexible response to changing market conditions (IOSCO 2002: 12) and of great impact on the relationship between firms and their environment (Golinelli, Gatti 2000-1: par. 3);

\footnotetext{
* The Authors: P. Di Betta $§ 2$; C. Amenta § 3; P. Di Betta and C. Amenta $\S ~ 1,4$

** Associate Professor of Management, University of Palermo (paolo.dibetta@unipa.it)

${ }^{* * * *}$ Lecturer in Management, University of Palermo (carlo.amenta@unipa.it)
} 
it could help investors to discriminate bad from good cases of corporate governance and it is an incentive-based tool for firms to screen themselves

In section 1 we suggest that in order to foster accountability by managers, a screening device should be build up so that firms have an incentive in revealing their technological expertise and managerial competences in corporate governance, including disclosure and transparency, mostly through a corporate governance Report. A self-regulatory organization (SRO) such as the stock exchange could administer the screening device, based on an indicator developed not only after corporate law and securities regulation but also on the provisions of the corporate governance code issued by the SRO itself. Section 2 is devoted to outline such a quality indicator for Italy, referred to the corporate governance code by Borsa Italiana, according to which we obtain a finer rating system. Some brief remarks on further improvements of the indicator close the paper.

\section{The Theoretical Argument}

Corporate governance is intermingled with the question of whether the firm is managed in the interests of shareholders or stakeholders (Tirole 1999). It is mostly concerned on aligning decisions and behaviour of the manager to aims and welfare improvement of shareholders, and consequently on performance and value creation; the relevance of corporate governance as a predictor of good performance is well established ${ }^{1}$.

The institutional frame of a country, even its legal origins matter: the relevance given to investor protection and the efficiency of the legal system in fostering shareholder value influence performance (La Porta et al. 1998, 2001). Evidence points, with increasing certitude, that corporate control and its market (management turnover, takeover defenses and so on), performance, capital structure, governance and ownership are interrelated and must be tested together (Bhagat, Jefferis, 2002). Along these lines, we sustain the relevance of an overall indicator to combine norms, rules and self-regulation in order to give a complete picture of corporate governance in a country.

Agency theory holds a perspective on corporate governance as an institutional setting to solve problems arising from hidden information (adverse selection) and hidden action (moral hazard); the former is mostly concerned with the information on the available technology for the firm, the latter deals with the ability, skills and effort of the managers who conduct the business itself.

The principal-agent paradigm has become a constitutive component of the new economics of regulation (Laffont, Tirole, 1993). In this section we draw an analogy: we consider any listed firm as if it were a public utility providing a peculiar added service to financial market: accountability and compliance. In this setting the regulator is loosely defined and represented as a plethora of institutions: legislative branch, government, security regulator, SRO (such as the stock exchange), all of them acting as a delegates by the market (investors, analysts, and so on).

From this perspective corporate governance is myopically biased towards reducing moral hazard problems, while those arising from adverse selection are mostly neglected. On the contrary, adverse selection plays a two-fold important role: in stock-picking and portfolio formation, due to the need to discriminate between good and bad cases of corporate governance; in regulation, due to the insurgence of an 
informational rent appropriated by the firm, thus asking for the introduction of an incentive scheme to induce firm to give up part of this rent. This is why we devote our attention to information disclosure aspects of corporate governance, considered as proxy for the care managers devote to accountability and compliance; the gist of our argument is that more attention to informational rent extraction (by the regulator) is requested in order to discriminate the bad firm form the good one. In this section we first draw attention on the price mechanism (subsection 2.1) and then on regulation (subsection 2.2).

\subsection{Corporate Governance and Price Formation}

As a matter of fact, corporate governance is also aimed at establishing an efficient monitoring (and accounting) structure to reveal the quality of managers in the business. They have hidden information on 'technology or productivity parameters' that generate the market value of the firm: information is needed by the financial community on these parameters that generate the cash flows of the firm. By communicating to the financial community they can (cautiously) release information on these, thus influencing the pattern of price formation (i.e., the probability density function of stock prices). Information on private knowledge regarding productivity parameters cannot be easily disclosed for strategic reasons, so we can use a proxy, i.e., the overall communication policy of the firm (disclosure and transparency).

Managers also reveal their competence in the process of communicating strategy, earnings prospects and investment plans (for assets in place and for growth opportunities of the firm), and in building up reputation and credibility through this signalling process, by doing so they screen themselves in matters of disclosure and compliance. It is the willingness-to-disclose by the firm which defines its type: whether it a good or a bad one in accountability and transparency. The available technology of disclosure of the firm is considered to be driven by law and regulation (which are well known to all the participants in the financial markets), but each firm must distinguish itself from the others and must have some instruments to show off its characteristics; we think corporate governance codes help as a screening device.

In this regard, yardstick competition refers to the comparison among firms according to the characteristics of their 'information-on-the-firm production function' (i.e., the production function of the communication and disclosure process itself), which concerns the revelation by the manager of his hidden knowledge on the strategy of the firm, and this is the extra public service listed firms have to provide to the market ${ }^{2}$.

Price formation depends on the interplay between macro (market-) level factors and micro (firm-) level ones. The latter are dealt with now, the former at the end of subsection 2.2.

At a micro level, the very process of disseminating information to the market is driven by managers and in the end by the monitoring (and accounting) structure of the firm. According to Damodaran (1985) the diffusion and timing of information effects the valuation of firms by the market: the communication process influences cash flows formation as it is perceived by the financial community and translated into prices through time. Both the structure and dynamics of events in the firm and the characteristics of the information process set up by the manager fuel the data generating process behind the probability density function of the prices of the 
securities of the firm. He shows (1985: 433) that the information process is articulated by managers along the following dimensions: the frequency and consistency in the communication (how often the signal is emitted and what is the time lag in the release), and the accuracy in the process (errors, omissions in the communication). By crossing these characteristics and the frim-specific, inner structure and dynamics of the events, the firm (more or less explicitly) establishes a policy of releasing important information concerning the moments of its price probability density function. It must not be forgotten that all of the moments of the distribution, including skewness and curtosis, become relevant when large risks are at stake. At the core of our proposal is the idea that the information process hinges on voluntary disclosure because it is deemed to be more significant by the financial community than mandatory information, which is considered as routine.

As stated above, adverse selection models are motivated by the search for the revelation of manager's private information about the technology that generates the cash flow of the firm and by his willingness to transmit and share it with the financial community, a discretional policy in the hands of the manager. We suggest to turn also to this other side of the agency problem mentioned at the beginning of the section, and to replenish the picture on corporate governance for each country by including the institutional setting: the role of regulators, SROs (such as stock exchanges), auditing firms and rating agencies, investors (a broad category to include the security industry in general: institutional investors, financial analysts, etc.), the market for corporate control, capital and ownership structure. Table 2.1 recapitulates what said thus far on agency problems and price formation, at micro and macro levels.

Table 2.1: A Synopsis of Agency Problems and Their Effects in Price Formation

\begin{tabular}{|c|c|c|c|c|c|}
\hline & \multicolumn{4}{|c|}{ Agency problems } & \\
\hline \multirow[b]{2}{*}{ Scopes $\downarrow$} & \multicolumn{2}{|c|}{$\begin{array}{l}\text { Hidden action } \\
\text { (Moral hazard) }\end{array}$} & \multicolumn{2}{|c|}{$\begin{array}{l}\text { Hidden information } \\
\text { (Adverse selection) }\end{array}$} & \\
\hline & \multicolumn{4}{|c|}{ Corporate governance } & desig \\
\hline $\begin{array}{l}\text { Effects on } \\
\text { investing parties: } \\
\text { performance, } \\
\text { efficient } \\
\text { monitoring } \\
\text { structure }\end{array}$ & $\begin{array}{l}\text { Effort in } \\
\text { business } \\
\text { profit }\end{array}$ & $\begin{array}{l}\text { Effort in } \\
\text { disclosure }\end{array}$ & $\begin{array}{l}\text { Knowledge } \\
\text { of business }\end{array}$ & $\begin{array}{l}\text { Knowledge } \\
\text { of technology } \\
\text { of disclosure }\end{array}$ & \multirow{2}{*}{$\begin{array}{l}\text { Role of } \\
\text { corporate control, } \\
\text { capital and } \\
\text { ownership } \\
\text { structure } \\
\text { plus } \\
\text { investors, auditing } \\
\text { firms, rating } \\
\text { agencies, SROs }\end{array}$} \\
\hline $\begin{array}{l}\text { Effects on non- } \\
\text { investing parties: } \\
\text { rendition and } \\
\text { effective } \\
\text { monitoring } \\
\text { structure }\end{array}$ & $\begin{array}{l}\text { Effort in } \\
\text { welfare } \\
\text { and well- } \\
\text { being }\end{array}$ & $\begin{array}{l}\text { Effort in } \\
\text { disclosure }\end{array}$ & $\begin{array}{l}\text { Concern on } \\
\text { social causes }\end{array}$ & $\begin{array}{l}\text { Knowledge } \\
\text { of technology } \\
\text { of disclosure }\end{array}$ & \\
\hline Price formation & \multicolumn{4}{|c|}{ at firm-level } & at market-level \\
\hline
\end{tabular}

When hidden information problem is alleviated, the part of the cash flows of the firm which is diverted by the manager is reduced and the value remaining in his hands has the nature of informational rent. Tirole (1999: par. 2.4) shows the relevance of passive monitoring in measuring rather than affecting the value of assets in place, and the role of performance measurement in increasing (pledgeable) income. Passive monitoring does not rise the net present value of investments directly but reduces 'the share of the 
cake' that needs to be allocated to the manager to provide him with adequate incentives. The stock price increases, thus reflecting the value of the firm more properly, due to a reduction in the tunneling of firm value to managers; the final result is an informational rent-extraction process by the market.

The essential component of accountability is information disclosure, either mandatory (legal, regulatory) or voluntary (self-regulatory, spontaneous). We mostly dedicate our attention to the latter aspect of accountability (of the voluntary type), and to disclosure patterns by the firm to the financial community (financial analysts, investors, shareholders) in relation to regulation and self-regulation.

When a firm goes public and is listed, a kind of contract is implicitly written between the firm and the financial community, mediated in a certain way by the stock exchange and by its rules, this setting is de facto a game of incomplete information, because some aspects of the disclosure technology are proprietary to the agent (the firm). The information resides within the firm and it is delivered according to its disclosure policy, conditioned by law, regulation, stock exchange rules, conventions and so forth. Implicit in the relationship between the market and the firm is a contract which is incomplete, since it fails to deliver observable and verifiable information on this disclosure technology by the firm. The incomplete contract concerning the technology of disclosure becomes a game in which the principal does not know the agent's type - its willingness-to-disclose (i.e., how eager is the firm to disclose information on its future prospects). Incomplete contracts are contingent on some moral hazard or adverse selection unobservable and latent variables (Laffont, Tirole 1993: 3 fn. 9): we include all of them under the heading 'accountability'. By adhering to self-restraints and customs (i.e., voluntary disclosure), the firm signals its type.

Having established that a broader version of corporate governance, which ends up in reducing also adverse selection problems, improves overall accountability to investors (actual and prospective), we now turn to regulation. We want to consider cases in which there is a continuous check by investors on the technology parameter (firm type), mediated by the presence of the regulator with an active role in screening, and in establishing a finer ranking of firms.

\subsection{Corporate Governance and Regulation}

By considering corporate governance as a problem of regulation we realize, as Laffont and Tirole (1993: 39-40) put it clearly, that there is a trade-off between effort inducement (due to moral hazard) and informational rent (due to adverse selection): 'Recall that the regulator faces moral hazard and adverse selection. The regulator is unable to monitor the firm's effort to reduce cost and has less information than the firm about technology.'. The first goal is aimed at fixing the incentives to induce the firm to be efficient - to reduce its costs. Some contracts imposed by the regulator are more effective: fixed-price contracts make the firm residual claimant for its cost savings, and in this regard are very powerful. The second goal is aimed at inducing the firm to adopt the available technology in production (best practices in managing the disclosure process, in our case), so the regulator (and the market it represents) can extract informational rent.

Regulation theory suggests a contract whose structure is in-between the two extremes represented by the 'price-cap' scheme on one side and by the 'cost-plus' scheme on the other. While actual security and stock market regulatory regimes 
have the form of a price-cap because they want to reduce moral hazard (attention is given to costs of providing good corporate governance), we sustain the opportunity to move towards cost-plus schemes, which are more likely to reduce informational rent by the manager and increase market rent-extraction, thus allowing the market to distinguish the good from the bad type of firms. In the end, a middle-of-the-road incentive contract would be the best choice. If the financial community is not informed of (un-)favorable events to the firm, they remain at the exclusive disposal of the firm and informational rent arises, which is very sensitive to the technological environment. The regulator, acting in the interests of the market, wants to extract this kind of rent deposited in the firm; in this case a cost-plusfixed-fee is favoured: 'a cost-plus contract is ideal for rent extraction' and so it is beneficial to the financial community.

The regulator's purpose should be to induce the firm to adopt this goal tied to hidden information; it is more important that the firm adopts the best practices available (at the most favourable cost). Firms face a trade-off because disclosure is costly, so a self-screening device is generated according to which firms reveal their technological competences in information disclosure to the market.

The setting being installed, it needs a screening procedure, fostered by the regulator, which should represent an self-enforcing incentive scheme for the firm. We propose an indirect reward-punishment system, by leveraging on Merton's idea (1987: 493; see infra) that in the market an additional discount rate is created by incomplete information. We show that by disentangling this premium the SRO introduces an incentive scheme analogous to a cost-plus regulatory contract, since a form of (indirect) rate-of-return regulation is an example of a cost-plus scheme. Moreover, notice that measuring consensus is a way to reveal how much noise trading (De Long et al. 1990) is present in the market; the argument is not developed here in full due to space limits.

The regulator might become an intermediary in disentangling that part of the rate of return applied by the market to evaluate the firm and in attributing it to the information-on-the-firm production function. This component of valuation, pertaining to market consensus, could be revealed to the community and some kind of informational rent extraction from the manager to the benefits of the SRO and market (the ultimate principal) would appear. This process will result in betterendowed firms in terms of information disclosure (accountability) to distinguish themselves from worse ones, and a continuum of types should appear, individuated according to this 'revealed' discount rate. The SRO is implicitly imposing a rateof-return incentive scheme, because it can calculate a rough measure of Mertontype discount rate present in the market, also with the help of analysts consensus. Indirectly, the SRO is extracting information rent from the good-type firm and is 'measuring the economy in disutility of effort associated with a better technology' (Laffont, Tirole 1993: 58).

Relative performance evaluation (yardstick competition) is a well accepted principle in financial markets, the capital asset pricing model (CAPM) being an example ${ }^{3}$. Yardstick competition in our case is a way to induce an incentive for the firm to reveal its quality in accountability and disclosure. The stock exchange should propose an overall index of transparency (information disclosure) and calculate a kind of rate of return correction for the stocks, including some sort of evaluation by financial analysts and market consensus. This information-related correction on the rate of return for the single stock could be applied by analysts to 
evaluate cash flows; this part of the risk factor of the firm can be attributed to the probability of certain events of the firm which involve great risks (some kind of surprise events, even bankruptcy) ${ }^{4}$.

It is useful then to go back briefly to the process of price formation hinted at in subsection 2.1, now considered at a macro level. Extensive evidence demonstrates that market value is influenced by the extension of firm's investor-base, by the number and reputation of the analysts who release reports on the firm, by the reputation of the firm itself in the financial community. Since investors have information only on a subset of securities, this form of incomplete information has an effect on equilibrium price that is 'similar to applying an additional discount rate' (Merton 1987: 493). As Merton shows, a modified-CAPM explains the neglectedstocks effect: since tracking some firms is costly for the investment bank, the presence of few analysts is representative of difficulties in analyzing the stock. This observation should be hampered by the contrary evidence that some firms require more analysts because of the inner complexity of the industry: a market-level tradeoff is thus formed, that parallels the firm-level one between the inner structure of events inside the firm and their voluntary release by managers, mentioned above after Damodaran (1985).

Both market-level and firm-level considerations support our idea that the regulator could administer an evaluation process through a survey to analysts in order to give an overall evaluation of the disclosure policy and transparency of the firm; the regulator acquires an important role in yardstick competition by disentangling purely idiosyncratic shocks from purely aggregate shocks, thus reducing informational asymmetries present in the market (see Laffont, Tirole 1993: par. 1.7).

The screening device reflects the two-tier structure of the price formation mechanism and can be articulated in a four-steps procedure around an indicator.

At the first step, the SRO develops an index based on the code of corporate governance (the Code Index) to assess with a grade the compliance of the firm to the Code; it would reflect micro-level price formation. A composed indicator based also on the law and on security regulation, called the Governance Indicator could include also more indices concerning norms and rules.

At the second step, SRO collects the market consensus on corporate governance for each firm, by aggregating evaluations on each firm given by financial analysts who track the stock. By using the same evaluation forms the stock exchange uses in its own assessment of the Code Index, it could be detected the perception of the market on the adherence by each firm to the rules of the Code. A grade is given, a kind of average evaluation 'from the floor' (at macro-level), which can closely track the grade obtained by the stock exchange itself: this is a first indication from financial analysts concerning the way the firm is perceived to respect the rules. The index from the second step can be called the Code Consensus. (Actually it could be the Governance Consensus, as above, if the indicator includes evaluation the Code and also on norms and regulation rules.)

The third step is characterized by an enlarged stream of variables of interest, as far as corporate disclosure is concerned, not included in the Code. This index includes variables such as the propensity to respond to questions concerning strategies in meetings with the financial analysts and other variables deemed of relevance to them. Again, questionnaires are circulated (for each firm) among analysts, to obtain a second index, complementary to that developed at step 2, to 
give an overall reputation of the firm in the market, it can be called the Reputation Consensus.

At a final, fourth step, the stock exchange could eventually present a final indicator mixing or adjusting the Code (or the Governance) Indicator with the Reputation Consensus, using the appropriate weights.

\section{An Index Based on Corporate Governance Code}

Recent legislative reform in Italy, effective from 2004, has allowed firms to shop around three 'models' of corporate governance: the Latin (pre-existent), the AngloSaxon (or monistic) and the German (or dualistic); they are considered equivalent options available to shareholders. It is interesting to notice that the Corporate Governance Code (Borsa Italiana, 2002), a self-regulation device introduced in 1999 and revised in 2002 under the auspices of the stock exchange included provisions which have been pasted into this new legislation.

We argue that the possibility of shopping among models is not a discriminating criterion to detect the quality of corporate governance of a single firm, but should be considered as some kind of conditioning variable for more voluntary and discretional compliance by firms. We lack benchmarks or references to compare the three models: inside our country we cannot use the adopted model as a signal of corporate governance quality. Once the legal model has been adopted, firms need more freedom in order to build up their reputation and credibility with the market: self-regulation could furnish a finer scale of options along which firms can position themselves to signal their quality.

Recent trend towards more precise and well-defined norms does not take into account that self-regulation could both improve the strategic levers firms can manoeuvre in order to signal their quality in corporate governance and at the same time guarantee more up-to-date adjustment to current needs of the market, to developments in theory and in best practices.

We present the framework for a quantitative indicator based on functional and technical quality to be applied to each legal model chosen by an Italian firm; the tool would be periodically revised to follow best practices: it represents an enhancement to market efficiency and a strategic tool for management. While waiting for a revision of the so called Preda Code after the aforementioned introduction of new legislation, we develop the indicator on the actual Code in its 2002 version.

Practitioners (rating agencies, consulting firms) and scholars are trying to define corporate governance rating tools: these proposals individuate an ideal set of corporate governance features in order to create an indicator that could be used for every firm whatever the business and the country of operations. Many of these indicators are based on the OECD principles on corporate governance (2004) and deal with six different areas: ensuring the basis for an effective corporate governance framework; the rights of shareholders and key ownership functions; the equitable treatment of shareholders; the role of stakeholders in corporate governance; disclosure and transparency; the responsibilities of the Board.

Indices can be used to forecast performance. Koehn and Ueng (forthcoming) cite several studies on best practices that encourage investors (especially institutional ones) to 'believe that best board practices are likely to benefit shareholders over the long haul'. These indices are considered useful by those who 'rely upon corporate 
governance metric systems that purport to reveal exactly how sound a particular company's governance is'. In their work they test two statistical hypothesis in order to understand if these metrics are good predictors of earnings quality and ethics (which in turn are considered the two essential features of a firm's best practice in management). They cite two main corporate governance metric systems: Governance Metrics International (GMI) ${ }^{5}$ and Institutional Shareholder Service (ISS) ${ }^{6}$; they conclude that GMI is not positively correlated to earning quality and ethics and choose the second one for the purpose of their study.

Gompers et al. (2003) present a Governance Index (GI) based on restrictions on shareholder rights (i.e., increased managerial power) that 'only consider the impact on the balance of power'

All of the tools just mentioned (GMI, ISS, GI) could be used by prospective shareholders wanting to invest in a country. According to GMI and ISS their ratings could be used to compare companies across countries, because they individuate universal dimensions always to be considered in corporate governance matters. We disagree with the underlying idea of this approach that an ideal corporate governance system exists, towards which every firm has to strive, and with the statement that indicators can be used in across-countries comparisons.

First of all we have to take into account the differences in legal origins of corporate governance laws, as La Porta et al. (1998: 3-4) have demonstrated: 'law and quality of its enforcement are potentially important determinants of what rights security holders have and how well these rights are protected'. In other words, it seems that it is important to underline how differences between legal systems in different countries are influenced by the country history and culture, because it could 'shed light on these corporate governance puzzles'.

We think that GMI and ISS (the GI is actually a domestic one) could underestimate the importance of legal systems influences on governance practice: they do not properly consider that every legal system concerning corporate laws is a mixture of the influences of different legal families. Moreover, none of them considers that it it least possible to identify the origin of a legal system, in order to assign it to a legal family and consequently modify the score to take into account of this aspect. This is why it is important to consider the country legal system as something fixed (some kind a conditioning variable, in a sense) and evaluate business culture when dealing with the creation of a corporate governance rating system. To accomplish this scope, we focus on corporate governance codes, because they involve different components of the financial community (practitioners, analysts, bankers, management scholars, law scholars, entrepreneurs, regulators and SROs) in the steering and technical committees, thus guaranteeing more up-to-date adjustment to current needs of the markets, to the developments in theory and in best practices, and proving more suitable in expressing the legal system and the business culture of the country.

If we individuate the corporate governance code as a good tool to signal the peculiarity of business culture and corporate best practice for each country, it is useful to use it in order to obtain a rating system whose score could become a variable to be analyzed for investor decisions.

We focus on the Italian Code to outline a framework for the indicator-building process that could be easily adopted to evaluate any country's corporate governance, thus increasing the comparability of the results obtained. We support the idea that there is an universal approach at building these indicators, by using 
service-quality evaluation system, and this is the only common ground across countries: the conceptual framework and methodology they share.

In order to create the index we refer to the statistical quality evaluation literature (Grönroos 1990): we consider corporate governance as a service and we evaluate its quality. In our case the service is information disclosure, that reduces the level of moral hazard and adverse selection risk.

Grönroos shows that quality is what is perceived by the clients, so it is fundamental to express corporate governance in terms of process in order to evaluate it as a service and to measure its quality. He distinguishes two different dimension of service quality: technical and functional quality; the former is related to the results and measures what the customer obtains; the latter refers to the process that allows a proper service deliver, thus obtaining the result that the customer desires.

In our case we have a process (the information-production function of the firm) and a result (corporate governance, the disclosure) that allows the customers (stakeholders: the financial community) to obtain what they desire (proper accountability). We consider technical and functional quality of corporate governance bodies (e.g., board, auditing committee, others) and processes (e.g., board meetings procedures, shareholders meeting rules, internal auditing committee procedures) in order to build the index based on the Italian Corporate Governance Code. Figure 3.1 summarizes our conceptual framework.

Figure 3.1 The CG Index Dimension

\begin{tabular}{|lll|}
\hline Procedures & $\rightarrow \rightarrow$ Functional quality (how) & $\rightarrow \mid$ \\
Features and composition & $\mid \rightarrow$ Corporate Governance quality \\
of CG bodies $\rightarrow \rightarrow$ Technical quality (what) & $\rightarrow \mid$ \\
\hline
\end{tabular}

Source: Grönroos (1990), with modifications

We define technical quality in a slightly different way from Grönroos in order to take into account the specificity of corporate governance mechanism: since the desired result of a service depends on its component parts, we consider the quality of corporate governance bodies, whose elements are: the number of independent board members, the presence of internal committees, the existence of specific rules for appointment of board members or for shareholders' meetings.

Each one of these components is evaluated by itself and so are the dynamic relations that arise among them. These processes are considered under the functional quality dimension that concerns the features of the corporate governance process and the way in which the corporate governance bodies interrelate.

In table 3.1 we present the variables considered for the index (specifying their functional or technical quality dimension) and obtained from the Italian Corporate Governance Code. The score for each variable is described in the second column, where we also consider a weighting hypothesis that could be used in order to obtain a more precise score an the source of information. For some variables we also individuate a benchmark that indicates the best practice and that is useful in order to assign the score. 
Table 3.1: The Variables for Corporate Governance Code Rating System

\begin{tabular}{|c|c|}
\hline $\begin{array}{c}\text { Variables } \\
\text { (Quality dimension) }\end{array}$ & $\begin{array}{l}\text { Description } \\
\text { (Source) }\end{array}$ \\
\hline $\begin{array}{l}\text { Board meeting are periodically held } \\
\text { and are effective } \\
\text { (Functional) }\end{array}$ & $\begin{array}{l}\text { The benchmark is once per month. The minimum score per year is twelve. Every } \\
\text { meeting scores one point and is weighted according to the importance of the } \\
\text { agenda. } 1 \text { for ordinary, } 0.5 \text { for less important and } 1.5 \text { for extraordinary. } 0 \text { if it is not } \\
\text { possibile to obtain the information. The presence of the majority of the board } \\
\text { members also accounts as a weighting coefficient. } 1 \text { if the } 50 \% \text { is reached, } 0.5 \text { if } \\
\text { not. (Board meetings minutes - and/or other informal sources or communications to } \\
\text { the market) }\end{array}$ \\
\hline $\begin{array}{l}\text { Presence of strategic, financial, } \\
\text { industrial plans (Functional) }\end{array}$ & $\begin{array}{l}\text { The score is one for every plan that is approved by the board } \\
\text { (Board meetings minutes }\end{array}$ \\
\hline $\begin{array}{l}\text { CEO or committee } \\
\text { (Technical) }\end{array}$ & $\begin{array}{l}\text { The score is } 1 \text { for presence and } 0 \text { for absence } \\
\text { (Board meetings minutes) }\end{array}$ \\
\hline $\begin{array}{l}\text { Number of board meetings held for } \\
\text { CEO or committee report (Functional) }\end{array}$ & $\begin{array}{l}\text { The benchmark is four per year. Every meeting scores one and the overall score } \\
\text { range from } 0 \text { (no meetings) to four (minimum). } \\
\text { (Board meetings minutes) }\end{array}$ \\
\hline $\begin{array}{l}\text { Number of assignments in other } \\
\text { boards for the board members } \\
\text { (Technical) }\end{array}$ & $\begin{array}{l}\text { The maximum number for listed company is } 5 \text {. The score is } 1 \text { for every member of } \\
\text { the board that has no more than } 5 \text { assignments. } \\
0.20 \text { is subtracted for every additional assignment, so that } 0 \text { is reached when the } \\
\text { overall number of assignments is } 10 \text { or more. The score obtained is divided for the } \\
\text { number of board members. } \\
\text { (Chamber of commerce, Borsa Italiana) }\end{array}$ \\
\hline $\begin{array}{l}\begin{array}{l}\text { Number of non executive board } \\
\text { members } \\
\text { (Technical) }\end{array} \\
\end{array}$ & $\begin{array}{l}\text { The benchmark is } 3 \text { out of } 5 \text {. The score range from } 0 \text { to } 1 \text { according to the ratio } \\
\text { calculated. } \\
\text { (Borsa Italiana, company records) }\end{array}$ \\
\hline $\begin{array}{l}\text { Number of independent board } \\
\text { members among the executive } \\
\text { (Technical) }\end{array}$ & $\begin{array}{l}\text { The benchmark is } 75 \% \text {. The score ranges from } 0 \text { to } 1 \text { according to the ratio } \\
\text { calculated. The definition of independent member is taken from the code. } \\
\text { (Borsa Italiana, company records, members survey) }\end{array}$ \\
\hline $\begin{array}{l}\text { The board members are well informed } \\
\text { before every board meeting } \\
\text { (Functional) }\end{array}$ & $\begin{array}{l}\text { A report on every topic on the agenda is sent to the board member at least five days } \\
\text { before the meeting. A signature of the board member on a copy of the report could } \\
\text { prove the delivery. }{ }^{(1)} \\
\text { The score is one if every member had the report, } 0.5 \text { if at least the majority had the } \\
\text { report, } 0 \text { if a minority had the report. } \\
\text { (Board meeting minutes) }\end{array}$ \\
\hline $\begin{array}{l}\text { Board rules to deal confidential inform } \\
\text { (2) (Functional) }\end{array}$ & ce and 0 for absence \\
\hline $\begin{array}{l}\text { Board rules to appoint board members } \\
\text { (Technical) }\end{array}$ & and 0 for absence \\
\hline $\begin{array}{l}\text { Internal committee to appoint board } \\
\text { members } \\
\text { (Functional) }\end{array}$ & $\begin{array}{l}\text { The score is } 1 \text { for presence and } 0 \text { for absence. The score is weighted with the } \\
\text { presence of independent members in the committee. The weight is } 1 \text { if the majority } \\
\text { of committee members are independent and } 0.5 \text { if there is a minority } \\
\text { (Board meetings minutes) }\end{array}$ \\
\hline $\begin{array}{l}\text { Internal committee for board members } \\
\text { remuneration } \\
\text { (Functional) }\end{array}$ & $\begin{array}{l}\text { The score is } 1 \text { for presence and } 0 \text { for absence. The score is weighted with the } \\
\text { presence of independent members in the committee. The weight is } 1 \text { if the majority } \\
\text { of committee members are independent and } 0.5 \text { if there is a minority } \\
\text { (Board meetings minutes) }\end{array}$ \\
\hline $\begin{array}{l}\text { Part of the board remuneration is } \\
\text { linked to performance } \\
\text { (Functional) }\end{array}$ & $\begin{array}{l}\text { The score is one if at least } 1 / 2 \text { of the remuneration is linked to performance, it is } 0 \text { in } \\
\text { other cases } \\
\text { (Board meetings minutes, remuneration committee minutes) }\end{array}$ \\
\hline $\begin{array}{l}\text { Internal committee for internal audit } \\
\text { procedures } \\
\text { (Technical) }\end{array}$ & $\begin{array}{l}\text { The score is } 1 \text { for presence and } 0 \text { for absence. The score is weighted with the } \\
\text { presence of independent members in the committee. The weight is } 1 \text { if the majority } \\
\text { of committee members are independent and } 0.5 \text { if there is a minority } \\
\text { (Board meetings minutes) }\end{array}$ \\
\hline $\begin{array}{l}\text { Number of board meetings dedicated } \\
\text { to internal audit report from the } \\
\text { committee and procedures revise } \\
\text { (Functional) }\end{array}$ & $\begin{array}{l}\text { The benchmark is two per year. The score is } 0 \text { if there is none, } 0.5 \text { if there is only } \\
\text { one and } 1 \text { for two meetings per year } \\
\text { (Board meetings minutes) }\end{array}$ \\
\hline $\begin{array}{l}\text { Number of internal audit committee } \\
\text { meetings with external auditors } \\
\text { (Functional) }\end{array}$ & $\begin{array}{l}\text { The benchmark is two per year. The score is } 0 \text { if there is none, } 0.5 \text { if there is only } \\
\text { one and } 1 \text { for two meetings per year } \\
\text { (Audit committee minutes) }\end{array}$ \\
\hline $\begin{array}{l}\text { Board rules for the relations with } \\
\text { linked company (Functional) }\end{array}$ & $\begin{array}{l}\text { The score is } 1 \text { for presence and } 0 \text { for absence } \\
\text { (Board meetings minutes) }\end{array}$ \\
\hline $\begin{array}{lrr}\text { A board member or committee is in } \\
\text { charge for the keeping relations with } \\
\text { relevant } & \text { stakeh. } & \text { (institutional } \\
\text { investors, } & \text { minority } & \text { shareh.) } \\
\text { (Techincal) } & & \end{array}$ & $\begin{array}{l}\text { The score is } 1 \text { for presence and } 0 \text { for absence } \\
\text { (Board meetings minutes) }\end{array}$ \\
\hline
\end{tabular}




\begin{tabular}{|c|c|}
\hline $\begin{array}{l}\text { Number of stakeholder relations } \\
\text { committee meetings with the } \\
\text { counterpart } \\
\text { (Functional) }\end{array}$ & $\begin{array}{l}\text { The benchmark is two per year. The score is } 0 \text { if there is none, } 0.5 \text { if there is only } \\
\text { one and } 1 \text { for two meetings per year } \\
\text { (Committee minutes) }\end{array}$ \\
\hline $\begin{array}{l}\text { Company rules for shareh. general } \\
\text { meeting. }{ }^{(3)} \text { (Technical) }\end{array}$ & $\begin{array}{l}\text { The score is } 1 \text { for presence and } 0 \text { for absence } \\
\text { (Company charter) }\end{array}$ \\
\hline $\begin{array}{l}\text { Shareh. has withdrawal right in case of } \\
\text { important variation in accounting } \\
\text { value, composition and number of } \\
\text { shareholders. (Functional) }\end{array}$ & $\begin{array}{l}\text { The score is } 1 \text { for presence and } 0 \text { for absence } \\
\text { (Company charter) }\end{array}$ \\
\hline $\begin{array}{l}\text { Internal committee for the } \\
\text { appointment of statutory auditors by } \\
\text { the shareholders } \\
\text { (Functional) }\end{array}$ & $\begin{array}{l}\text { The score is } 1 \text { for the presence and } 0 \text { for the absence. The score is weighted with } \\
\text { the presence of independent members in the committee. The weight is } 1 \text { if the } \\
\text { majority of committee members are independent and } 0.5 \text { if there is a minority } \\
\text { (Board meetings minutes) }\end{array}$ \\
\hline \multicolumn{2}{|c|}{$\begin{array}{l}\text { Notes to table } 3.1 \\
\text { (1) For the variable 'The board members are well informed before every board meeting'. There is not a reasonable way to } \\
\text { verify this procedure and this could be a serious problem, due to confidential information. } \\
\text { (2) For the variable 'Board rules for the management of confidential information'. We do not consider insider dealing aspects } \\
\text { here, only because we want to preserve the link with the Code: it considers only 'confidential information' in general. } \\
{ }^{(3)} \text { For the variable 'Company rules for the shareholder general meeting'. Here another indicator could be developed because } \\
\text { general features of the shareholders' meeting are already fixed by some listed companies. }\end{array}$} \\
\hline
\end{tabular}

We realize that the weights could be obtained by statistical methods, but our intent at the moment is mainly to individuate the variables derived from the Italian code and to describe how these variables could account for the index overall score. They could be also considered in a benchmark established by the regulator or the SRO in order to set different priorities for different aspects of good corporate governance practices. In the Italian case the stock exchange has maintained a separation of segments of the market, according to which the listing on one segment implies more quality in corporate governance compliance. In that case the weights could be assigned in order to differentiate the listed companies that belong to different segments and to set the standards of access.

We closely follow the specifications of the Italian Code and we suggest the score of some of variables in order to define what has to have more weight on the overall score. We are aware that some of the variables could be redundant (collinear) when we consider also charter rules imposed by law but we want to preserve a strict link to the Code in its actual version, to be updated after the recent reform. These embellishments are left for further study.

The index is built as an additive model and we can obtain an overall grade and the scores for each dimension (technical and functional).

By referring to quality-evaluation process and to the described dimensions we obtain a tool to improve upon the three indicators described above: this process is a good way to take into account differences in the legal systems among countries, thus improving the efficiency of the tools. Gompers et al. (2003) take into account the legal system by considering anti take-over laws in their indicator, thus focussing only on a part of the framework that influences a corporate governance system. Our indicator could refine theirs because each code is capable of catching the legal system influences in a more precise way.

In our case the presence of technical dimension allows us to include in the information relevant for investors, an improvement to the GMI rating system which does not includes this information in the overall score, with a reduced signalling performance. Moreover, by weighting the variables and the features of institutional components, the tool could be more precise if used to evaluate firms. The distinction between technical and functional quality could also help in analyzing the relations between corporate governance and financial performance. 
As expressed at the end of section 2, another index could be used to correct the corporate governance rating. According to Grönroos corporate image is the lens that corrects the service quality before it is perceived by the customer. In that sense analyst consensus could be considered as a proxy for the reputation and credibility of the firm, thus representing the lens that effects the firm's corporate governance perception by the investors; this concept is shown in figure 3.2.

The overall score obtained with the consensus indicator could be used together with the other one to obtain the final grade. It is left for further investigation if it must be added or multiplicative.

Figure 3.2 The Effect of Analysts Consensus on CG Quality Perception

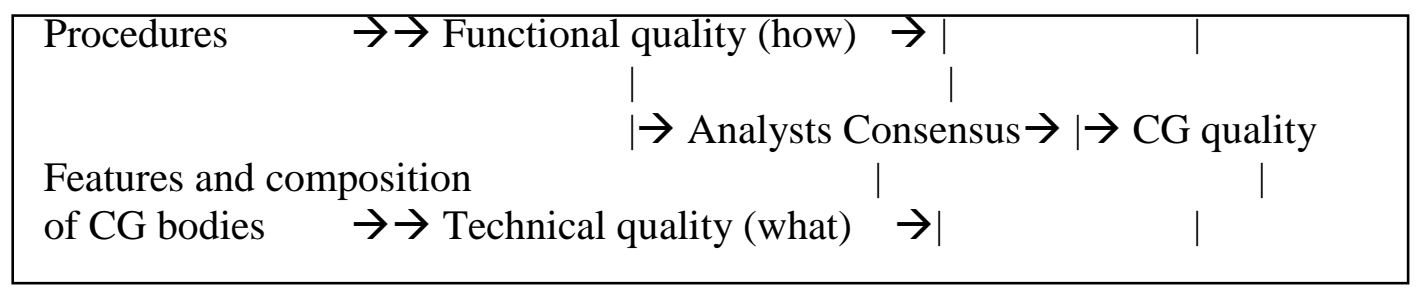

Source: Grönroos (1990), with modifications

\section{Conclusions: the Way Forward}

Our proposal concerns how to force firms to disclose, as a way to assess their accountability and the characteristics of their information-on-the-firm production function. We look for an incentive contract that induces the firm to comply, giving more power to a self-regulatory organization, the stock exchange itself. We end up suggesting a indirect form of correction to the rate of return used in the market and diffused by the regulator: by doing so, we disentangle a correction factor to widely used factor pricing models, to detect a kind of risk component of the stock implied by the corporate governance policy adopted by the firm.

Our aim is to create a tool to measure corporate governance along the dimensions of disclosure. Holding legal origins (or the model adopted, in Italy) as fixed, country codes of corporate governance can allow firms to display their inner characteristics. This preliminary version of the indicator needs testing to check the weighting hypotheses. La Porta et al. (1998) consider the quality of accounting standards (deemed a consequence of disclosure rules) but do not explicitly analyze disclosure rules, it would then be of particular interest to study the conjoint effect of these dimensions: our indicator could result in a useful complement to theirs.

As is evident in the paper, we have not presented the dimensions of the analysts consensus index, which must therefore be articulated.

\section{Bibliography}

Bhagat S., Jefferis R.H. jr., The Econometrics of Corporate Governance Studies, Cambridge MA USA, MIT Press, 2002.

Borsa Italiana - Comitato per la Corporate Governance delle Società Quotate, Codice di autodisciplina delle società quotate rivisitato (Luglio 2002), July, 2002. 
Damodaran A., Economic Events, Information Structure, and the Market Generation Process, Journal of Financial and Quantitative Analysis, 20, 4, December, 1985, pp. 423-434.

http://dx.doi.org/10.2307/2330759

De Long B.J., Shleifer A., Summers L.H., Waldman R.J., Noise Trader Risk in Financial Market, Journal of Political Economy, 98, 4, 1990, pp. 703-738. http://dx.doi.org/10.1086/261703

Gompers P.A., Ishii J.L., Metrick A., Corporate Governance and Equity Prices, Quarterly Journal of Economics, 118, 1, 2003, pp. 107-155. http://dx.doi.org/10.1162/00335530360535162

Golinelli G.M., Gatti M., The Firm as a Viable System, Symphonya. Emerging Issues in Management (symphonya.unimib.it), n. 2, 2000-2001. http://dx.doi.org/10.4468/2001.2.04golinelli.gatti

Grönroos C., Service Management and Marketing. Managing the Moments of Truth in Service Competition, Lexington Books, D.C, 1990.

IOSCO - International Organization of Securities Commissions, Objectives and Principles of Securities Regulation, February, 2002.

Koehn D., Ueng J. (forthcoming), Evaluating the Evaluators: Should Investors Trust Corporate Governance Metrics Ratings, Journal of Management and Governance, 9. http://dx.doi.org/10.1007/s10997-005-4027-8

Lambin J.J., Brondoni S.M., Overture de 'Market-Driven Management', Symphonya. Emerging Issues in Management (symphonya.unimib.it), n. 2, 2000-2001. http://dx.doi.org/10.4468/2001.2.01ouverture

Laffont J.J., Tirole J., A Theory of Incentives in Procurement and Regulation, Cambridge USA, MIT Press, 1993.

La Porta R., Lopez-de-Silanes F., Shleifer A., Vishny R.W., Law and Finance, Journal of Political Economy, December, 1998.

La Porta R., Lopez-de-Silanes F., Shleifer A., Vishny R.W., Investor Protection and Corporate Valuation, Working Paper, Harvard University, 2001.

Merton R. C., A Simple Model of Capital Market Equilibrium with Incomplete Information, Journal of Finance, XLII, 3, July, 1987, pp. 483-510.

http://dx.doi.org/10.2307/2328367

OECD - Organization for Economic Cooperation and Development, OECD Principles of Corporate Governance, 2004.

\section{Notes}

${ }^{1}$ Gompers et al. (2003) build up portfolios using stocks picked up from different deciles of their Governance Index: by buying from the lowest decile (strongest corporate governance) and selling from the highest decile (worst corporate governance) they show abnormal returns of $8,5 \%$ per year in the sample period. Bad corporate governance is associated with lower profits, lower sales growth, higher capital expenditure and amount of corporate acquisitions, thus giving strong evidence of profound relation between corporate governance and performance.

2 The 'information-on-the-firm production function' can be assimilated to the production function of the products sold by the firm and to other marketing-costs function (Merton 1987: 501). We can only briefly mention here the relevance of hidden information disclosure from the standpoint of a full-fledged market-driven management (Lambin and Brondoni 2000-1), especially when considered at a corporate level: in this case the 'client' is the financial community. An outstanding example is Fed Governor Alan Greenspan, a maestro in disclosing information on the policies that will be pursued: he shows a high level of efficiency and effectiveness in disclosure (i.e., a high level of significance at a low cost, even counting words said). The whole Fed structure is also considered an example of extreme reliability in information disclosure on the economy (e.g., the Beige book and other recurrent releases of information). 
${ }^{3}$ The CAPM is based on this principle since it compares the rate of return of any asset to the rate of return of an index which is deemed representative of the overall economy, or to a lesser extent, of the stock market.

${ }^{4}$ The idea is that it could be applied either inside revised-CAPM models such as Merton's, which has been our main reference, or in other multiple-beta models, and indeed will result in a strong deterrent against bad corporate governance practices.

5 The GMI rating system (www.gmiratings.com) consists of six different categories: board accountability; financial disclosure and internal controls; shareholder rights; executive compensation; market for control and ownership base; corporate behavior and corporate social responsibility issues. Each receives a score that is then added to obtain an overall grade. All companies rated by GMI are graded on a scale from 1.0 (lowest) to 10.0 (highest). The company ratings are calculated relative either to other rated companies in the same region or country of origin (the company's 'home market' rating) or to the 3,200+ companies rated by GMI worldwide ('global rating'). Together with this rating every subscriber receives a report where some additional information not considered in the index score is given: a rating history for both the company and its industry, summary statistics for the board of directors. In the report each of the three key committees (audit, compensation and nomination/governance) are profiled, and each member of the board, too. Each director's profile includes a classification as either independent or non-independent, according to GMI guidelines and an explanation, when directors are classified as non-independent. These additional corporate governance features are not inserted in the general indicator but considered autonomously.

${ }^{6}$ The ISS (www.issproxy.com) bases its rating on 63 variables, including board committee structure, board size, number of boards on which individual director serve, board guidelines, the number of independent directors, directors' attendance at the meetings, board responsiveness to shareholder proposals.

7 The index is composed of five categories: delay, protection, voting, State, other. The Governance Index results from the sum of the points gained for each of the 28 provisions: one for the existence and zero for the absence; the higher the score, the less the shareholder protection. 